ISSN 0258-7122

Bangladesh J. Agril. Res. 34(3) : 435-442, September 2009

\title{
EFFECT OF DIFFERENT LEVELS OF NPK FERTILIZERS AND IRRIGATION ON YIELD AND NUTRITIVE QUALITY OF MULBERRY LEAF
}

\author{
N. K. PAUL ${ }^{1}$ AND M. A. QAIYYUM ${ }^{2}$
}

\begin{abstract}
Experiment was conducted at the research field of Bangladesh Sericulture Research and Training Institute, Rajshahi in 2001-2002 and 2002-2003 to investigate the effect of NPK fertilizers and frequency of irrigation on leaf yield, yield components and leaf quality characters of three mulberry varieties. Four levels of NPK fertilizers and three levels of irrigation were adopted. The treatments comprising $300 \mathrm{~kg} \mathrm{~N}, 150 \mathrm{~kg} \mathrm{P}$, and $100 \mathrm{~kg} \mathrm{~K} / \mathrm{ha} / \mathrm{yr}$ along with two irrigations in a month was found to be the best for higher leaf yield, leaf moisture and leaf nutrient contents of mulberry plants (var. BM-3).
\end{abstract}

Key Words: Mulberry, NPK fertilizers, irrigation, nutritive quality.

\section{Introduction}

Mulberry leaf production is often limited by the amount of available soil moisture and it can be increased by supplemental irrigation (Jolly, 1986). Kasiviswanathan and lyengar (1965) observed that irrigation increased leaf yield of mulberry plants by about $68 \%$. The irrigation given during November-April (drought period) about 15 days interval outyielded monthly irrigation (Mukherjee el al., 1972; Rangaswami et al., 1976).

The importance of NPK fertilizers for both increased productivity and improved quality of mulberry leaves has been well recognized. The yield of mulberry is influenced more by the amount of nitrogenous fertilizer than phosphorus and potassim (Pain, 1965; Kasiviswanathan et al., 1979; Islam et al., 1982 and 1985).

In Bangladesh, a balanced dose of NPK fertilizers with appropriate frequency of irrigation should be fixed up to achieve the maximum yield potential of mulberry leaves. The present piece of experiment was undertaken in an attempt to find out the optimum doses of NPK fertilizers with an irrigational frequency that would give maximum leaf yield with least of cost.

\section{Materials and Method}

The experiment was conducted at the experimental field of Bangladesh Sericulture Research and Training Institute, Rajshahi, Bangladesh. The soil of the

\footnotetext{
${ }^{1}$ Department of Botany, Rajshahi University, Rajshahi, ${ }^{2}$ Bangladesh Sericulture Research and Training Institute, Rajshahi, Bangladesh.
} 
experimental field was sandy clay loam with $\mathrm{pH}$ 7.2. The total nitrogen was $0.08 \%$, phosphorus $0.36 \%$, potassium $30.30 \%$, organic matter $0.77 \%$ and C.E.C. (cation exchange capacity) $18.30 \mathrm{me} / 100 \mathrm{~g}$.

Three improved mulberry varieties viz., BM-l, BM-2 and BM-3 were used. NPK fertilizers were applied in the form of urea, TSP, and MP, respectively. Four doses (treatment) were as follows (kg/ha/yr) (Quader et al., 1992):

\begin{tabular}{lllllll}
\hline \multicolumn{2}{c|}{ Treatments } & \multicolumn{1}{c|}{$\mathrm{N}$} & & $\mathrm{P}$ & & $\mathrm{K}$ \\
\hline $\mathrm{T}_{0}$ & 0 & 0 & & \\
$\mathrm{~T}_{1}$ & 200 & 100 & 75 & \\
$\mathrm{~T}_{2}$ & 300 & 150 & 100 & \\
$\mathrm{~T}_{3}$ & 400 & 200 & 125 & \\
\hline
\end{tabular}

Fertilizer doses were applied in two splits following the two seasons of irrigation during the drought period (November-April) of 2001-02 and 2002-03. There were 3 levels of irrigation as $l_{0}=$ No irrigation, $I_{1}$ One irrigation at the middle of the month and $1_{2}=$ Two irrigations in a month (15 days interval). On each occasion, 2 acre-inch irrigation water was applied. The experimental design was split split plot with three replications.

The irrigation practice was done during the drought period of the year and as experimental schedule, season 1 (February-April) of 2002 and season 2 (November-January) of 2002-03. There were two harvests for two seasons. Each harvest was done at 90 days after planting (DAP) and the following characters were recorded:

A. For leaf yield and its components: plant height, number of branches/ plant, number of leaves/branch and leaf yield/plant.

B. For leaf quality: Moisture (\%), protein (\%), reducing sugar (\%), total sugar (\%), soluble carbohydrate (\%), minerals (\%) and N(\%).

C. Data were analyzed statistically.

The meteorological data were collected from the regional Meteorological Station, Shympur, Rajshahi, which is about $2 \mathrm{~km}$ from the experimental field. Information like average monthly temperature, rainfall, and relative humidity (RH) are shown below: 


\begin{tabular}{|c|c|c|c|c|c|c|c|c|c|c|c|c|c|}
\hline & & Jan & Feb & March & April & May & June & July & Aug & Sept & Oct & Nov & Dec \\
\hline \multirow{3}{*}{$\begin{array}{l}\text { Tern. } \\
\left({ }^{\circ} \mathrm{C}\right)\end{array}$} & 2001 & 17 & 21 & 26 & 29 & 30 & 29 & 30 & 30 & 29 & 27 & 22 & 19 \\
\hline & 2002 & 17 & 19 & 25 & 30 & 30 & 29 & 29 & 29 & 27 & 27 & 23 & 18 \\
\hline & 2003 & 17 & 21 & 24 & 28 & 29 & 29 & 29 & 29 & 29 & 28 & 24 & 18 \\
\hline \multirow{3}{*}{$\begin{array}{l}\text { Rain } \\
\text { fall } \\
(\mathrm{mm})\end{array}$} & 2001 & 6 & 24 & 10 & 25 & 129 & 245 & 304 & 92 & 310 & 223 & 24 & 22 \\
\hline & 2002 & -- & -- & 33 & 12 & 122 & 85 & 249 & 186 & 124 & 132 & 10 & -- \\
\hline & 2003 & -- & 5 & 55 & 70 & 156 & 343 & 241 & 177 & 316 & 157 & 54 & -- \\
\hline \multirow{3}{*}{$\begin{array}{l}\text { RH } \\
(\%)\end{array}$} & 2001 & 84 & 66 & 58 & 57 & 77 & 84 & 84 & 85 & 89 & 876 & 72 & 70 \\
\hline & 2002 & 83 & 73 & 55 & 48 & 67 & 84 & 86 & 82 & 78 & 80 & 78 & 75 \\
\hline & 2003 & 81 & 74 & 62 & 49 & 59 & 74 & 81 & 84 & 86 & 87 & 83 & 82 \\
\hline
\end{tabular}

\section{Results and Discussion}

\section{Leaf yield and its components}

Mean values of leaf yield and the components of three mulberry varieties as influenced by NPK fertilizers and irrigation over seasons and years are presented in Table 1.

Table 1. Leaf yield and yield components of three mulberry varieties as influenced by NPK fertilizers and irrigation.

\begin{tabular}{ll|l|l|l}
\hline & Plant height $(\mathrm{cm})$ & $\begin{array}{c}\text { Branch } \\
\text { number/plant }\end{array}$ & $\begin{array}{c}\text { Leaf } \\
\text { number/branch }\end{array}$ & $\begin{array}{c}\text { Leaf yield/plant } \\
(\mathrm{g})\end{array}$ \\
\hline \multicolumn{5}{c}{ Varietal effect } \\
BM-I & 130.25 & 10.25 & 32.92 & 188.24 \\
BM-2 & 95.92 & 9.41 & 25.18 & 162.36 \\
BM-3 & 117.60 & 11.90 & 30.13 & 194.07 \\
\hline LSD 5\% & 2.15 & 0.56 & 0.72 \\
\hline \multicolumn{5}{c}{ NPK fertilizer effect } \\
\hline $\mathrm{T}_{0}$ & 104.47 & 9.42 & 27.06 \\
$\mathrm{~T}_{1}$ & 113.24 & 10.49 & 29.18 & 140.74 \\
$\mathrm{~T}_{2}$ & 117.50 & 11.02 & 30.06 & 177.28 \\
$\mathrm{~T}_{3}$ & 123.06 & 11.68 & 31.19 \\
\hline LSI) 5\% & 1.86 & 0.48 & 210.11 \\
\hline \multicolumn{5}{c}{0.68} \\
\hline $\mathrm{I}_{0}$ & 96.89 & Irrigation effect \\
$\mathrm{I}_{1}$ & 118.59 & 11.25 & 26.46 \\
$\mathrm{I}_{2}$ & 178.27 & 11.71 & 32.75 \\
\hline LSD 5\% & 2.15 & 0.57 & 119.17 \\
\hline \multicolumn{5}{c}{0.79} \\
\hline
\end{tabular}




\section{Effect of variety}

There were significant differences between the varieties for all the characters studied. Among the varieties, BM-1 had significantly higher values for plant height, leaf number/branch followed by BM-3 and BM-2. But branch number/plant and leaf yield/plant were significantly higher in BM-3 followed by BM-1 and BM-2. Leaf yield/plant in BM-3 was $194.0 \mathrm{~g}$ and those of BM-l and BM-2 were $188.24 \mathrm{~g}$ and $162.36 \mathrm{~g}$, respectively (Table 1). This confirms the previous findings in mulberry (Miah, 1989).

\section{Effect of NPK fertilizers}

Application of NPK fertilizers significantly increased all the characters over the control (no NPK). Among the fertilizer treatments, $T_{3}(400 \mathrm{~kg} \mathrm{~N}, 200 \mathrm{~kg} \mathrm{P}$ and $125 \mathrm{~kg} \mathrm{~K} / \mathrm{ha} / \mathrm{yr}$ ) showed significantly the highest values for all these characters. On the other hand, $\mathrm{T}_{0}$ had the lowest values. Such result was reported by Miah (1989) that by the application of N, P, and K fertilizers at the rate of 400 $\mathrm{kg} \mathrm{N}, 200 \mathrm{~kg} \mathrm{P}$, and $150 \mathrm{~kg} \mathrm{~K} / \mathrm{ha} / \mathrm{yr}$, leaf yield was increased by $77.92 \%$ over the control. Ray (1978) applied N fertilizer at the rate of 150, 300, 600, and 900 $\mathrm{kg} / \mathrm{ha} / \mathrm{yr}$ and observed that leaf yield increased by $88 \%$ in the highest dose. Compared to the control $\left(\mathrm{T}_{0}\right)$, leaf yield/plant of $\mathrm{T}_{1}, \mathrm{~T}_{2}$, and $\mathrm{T}_{3}$ was increased by 25.96, 41.60 and $49.29 \%$, respectively. The importance of fertilizers on leaf yield of mulberry has also been reported by Ahmad (1986), Islam et al. (1982 and 1985), Kasiviswanathan and lyengar (1965, 1966, 1969 and 1970), Subbarayappa et al. (1994), Mukherjee and Sengupta (1978) and Kasiviswanathan et al. (1977).

\section{Effect of irrigation}

There were significant effect of the frequency of irrigation treatments on leaf yield and its components (Table 1). Of the three irrigation treatments, $1_{2}$ had higher values for all the characters followed by $1_{1}$ and $1_{0}$. The leaf yield/plant was $225.60 \mathrm{~g}$ in $1_{2}$ and $199.87 \mathrm{gm}, \mathrm{I}_{1}$, whereas $\mathrm{I}_{0}$ showed $119.17 \mathrm{~g}$. The leaf yield increased by $89.31 \%$ and $67.72 \%$ in $1_{2}$ and $l_{1}$, respectively, over $1_{0}$ (Table 1 ). Mukherjee et al. (1972) reported that fortnightly irrigation in mulberry outyielded monthly irrigation, while the yield was least in the non-irrigated condition.

\section{Leaf quality characters}

Mean leaf nutrient values of the three mulberry varieties under the treatment of NPK fertilizers with frequency of irrigation are shown in Table 2.

\section{Effect of variety}

Among the varieties, BM-3 showed significantly highest leaf nutrients except for moisture, which is highest in BM-2. 


\section{Effect of NPK fertilizers}

The nutritional components of mulberry leaf, such as leaf moisture, crude protein, reducing sugar, total sugar, starch, soluble carbohydrate and $\mathrm{N}$ increased significantly due to NPK fertilizers except for mineral content, which was decreased with the increased doses of NPK fertilizers.

Table 2. Leaf nutritional characters of three mulberry varieties as influenced by NPK fertilizers and irrigation.

\begin{tabular}{|c|c|c|c|c|c|c|c|c|}
\hline Treat. & $\begin{array}{c}\text { Moisture } \\
(\%)\end{array}$ & $\begin{array}{l}\text { Crude } \\
\text { protein } \\
(\%)\end{array}$ & $\begin{array}{c}\text { Rducing } \\
\text { sugar } \\
(\%)\end{array}$ & $\begin{array}{l}\text { Total } \\
\text { sugar } \\
(\%)\end{array}$ & $\begin{array}{c}\text { Starch } \\
(\%)\end{array}$ & \begin{tabular}{|c} 
Soluble \\
carboh- \\
ydrate \\
$(\%)$
\end{tabular} & $\begin{array}{c}\text { Minerals } \\
(\%)\end{array}$ & $\begin{array}{c}\text { Nitrogen } \\
\text { (\%) }\end{array}$ \\
\hline \multicolumn{9}{|c|}{ Varietal effect } \\
\hline BM-l & 72.98 & 19.34 & 2.50 & 4.36 & 13.60 & 17.96 & 9.04 & 3.16 \\
\hline BM-2 & 73.16 & 1974 & 2.72 & 4.45 & 13.65 & 18.11 & 8.89 & 3.16 \\
\hline BM-3 & 72.26 & 20.07 & 2.80 & 4.68 & 13.75 & 18.42 & 8.97 & 3.20 \\
\hline LSD 5\% & 0.10 & 0.10 & 0.06 & 0.06 & 0.12 & 0.06 & 0.26 & 0.06 \\
\hline \multicolumn{9}{|c|}{ NPK fertilizer effect } \\
\hline $\mathrm{T}_{0}$ & 71.83 & 18.18 & 1.68 & 3.23 & 12.72 & 15.95 & 9.04 & 2.90 \\
\hline $\mathrm{T}_{1}$ & 72.79 & 19.17 & 2.56 & 4.60 & 13.50 & $18.1 \mathrm{I}$ & 8.99 & 3.08 \\
\hline $\mathrm{T}_{2}$ & 73.11 & 20.26 & 3.02 & 4.89 & 14.07 & 18.96 & 8.95 & 3.28 \\
\hline $\mathrm{T}_{3}$ & 73.45 & 21.30 & 3.34 & 5.26 & 14.38 & 19.63 & 8.88 & 3.44 \\
\hline LSD 5\% & 0.08 & 0.08 & 0.05 & 0.05 & 0.10 & 0.51 & 0.22 & 0.05 \\
\hline \multicolumn{9}{|c|}{ Irrigation effect } \\
\hline $\mathrm{I}_{0}$ & 70.82 & 19.47 & 2.52 & 4.35 & 13.43 & 17.79 & 8.97 & 3.15 \\
\hline $\mathrm{I}_{1}$ & 73.64 & 19.75 & 2.69 & 4.52 & 13.66 & 18.19 & 9.00 & 3.18 \\
\hline $\mathrm{I}_{2}$ & 73.92 & 19.95 & 2.83 & 4.61 & 13.90 & 18.52 & 8.93 & 3.21 \\
\hline LSD 5\% & 0.10 & 0.10 & 0.06 & 0.06 & 0.12 & 0.06 & 026 & 0.06 \\
\hline
\end{tabular}

\section{Effect of irrigation}

The irrigation treatment $1_{2}$ (two irrigations in a month) showed the highest values in respect of the all the nutritional components of mulberry leaf except for mineral content. On the other hand, control treatment $\left(\mathrm{I}_{0}\right)$ showed the least values for all the nutritional components except for mineral content, which was least in $1_{2}$ treatment. 
Several workers have reported similar results. Miah (1989) observed that with the progressive increase of NPK fertilizers, leaf constituents like moisture, crude protein, total sugar, reducing sugar, starch and soluble carbohydrate contents increased gradually but mineral content decreased. It was also reported by Quader et al. (1972) that crude protein, sugar, and leaf moisture increased and mineral content decreased by the application of increased dose of fertilizer. Roy and Chi ya (1972) observed that fortnight irrigation increased moisture content, starch content and total carbohydrate, but not crude protein, which was slightly decreased in comparison to monthly irrigation.

\section{Economics of NPK fertilizers with irrigation}

From Table 1, it is observed that leaf yield increased significantly by the increasing doses of NPK fertilizers and frequency of irrigation, but the rate of increase gradually declined. This finding directed to evaluate a comparative performance of economic gain in leaf yield production against the different NPK fertilizer doses and frequency of irrigation. The costing of $1 \mathrm{~kg}$ leaf production reveals the fact that with the increase of NPK fertilizer doses and frequency of irrigation, leaf production cost decreased upto a certain limit and after that it increased upward. The costing was less when NPK fertilizers with two irrigations in a month in comparison to NPK fertilizers with one irrigation in a month except in $\mathrm{T}_{0} 1_{2}$ (data not shown). From the result, it is clear that $\mathrm{T}_{2} \mathrm{l}_{2}(300 \mathrm{~kg} \mathrm{~N}, 150 \mathrm{~kg} \mathrm{P}$ and $100 \mathrm{~kg} \mathrm{~K} / \mathrm{ha} / \mathrm{yr}$ ) with two irrigations in a month) was the most economic dose. This result corroborates the findings of Islam et al. (1982) and Miah (1989), where the cost of leaf production per kg was lowest with $300 \mathrm{~kg} \mathrm{~N}, 150$ $\mathrm{kg} \mathrm{P}$, and $100 \mathrm{~kg} \mathrm{~K} / \mathrm{ha}$ under natural environment. Kasiviswanathan et al. (1977) obtained increased leaf yield against the increased doses of $\mathrm{N}$ fertilizer upto 900 $\mathrm{kg} \mathrm{N} / \mathrm{ha}$, but economic evaluation confirmed that $300 \mathrm{~kg} \mathrm{~N} / \mathrm{ha}$ was the most economic dose for mulberry leaf yield.

In the present experiment, though leaf yield was increased with the increased dose of NPK fertilizers upto $400 \mathrm{~kg} \mathrm{~N}, 200 \mathrm{~kg} \mathrm{P}$, and $159 \mathrm{~kg} \mathrm{~K} / \mathrm{ha}$ with two irrigations in a month, but from the point of view of economics, application of $300 \mathrm{~kg} \mathrm{~N}, 150 \mathrm{~kg} \mathrm{P}$, and $100 \mathrm{~kg} \mathrm{~K} /$ ha with two irrigations in a month appeared to be the optimum dose of NPK fertilizers and frequency of irrigation.

\section{References}

Ahmed, M. 1. 1986. Effect of nitrogen fertilizer (urea) on Morus alba leaf yield. Pak. J. For.36: 19-22.

Islam, R., M. A. Bari and Z. Ahsan. 1982. Effect of different levels of fertilizers on leaf yield of mulberry under the irrigated condition. Bangladesh J. Agric. 6-7: 25- 30. 
Islam, R., M. A. Bari and R. Ali. 1985. Effect of nitrogen, phosphorus and potassium and their combination on the leaf yield of mulberry. J. Asiatic Soc. Bangladesh (Sc.). 11: 1-5.

Jolly, M. S. 1986. Economics of sericulture under irrigated conditions. CSRTI. Srirarnpuram. 1-17.

Kasiviswanathan. K. and M. N. Sitarama Iyengar. 1965. Preiliminary observation on varietal cum irrigational response to different levels of $\mathrm{N}$ on the seasonal and total yield of mulberry leaf. Indians J. Seric.4: 4-10.

Kasiviswanathan, K. and M. N. Sitarama lyengar. 1966. Effect of NPK manuring on seasonal and total yield of mulberry. Indian J. Seric. 5: 46-51.

Kasiviswanathan, K. and M. N. Sitararna lyengar. 1969. Varietal-cum irrigational response to different $\mathrm{N}$ levels on the seasonal and total yield of mulberry. SIB, 1: 1-12.

Kasiviswanathan, K. and M. N. Sitarama Iyengar. 1970. Effect of plant densities, methods of leaf harvest and nitrogen fertilization on the leaf yield of irrigated mulberry in Mysore State. Indian J. Seric. 9: 43-48.

Kasiviswanathan, K., S. Krishnaswami and C. V. Venkataraman. 1977. Studies on varietal-cum spacing and nitrogen fertilization on the leaf yield of mulberry under irrigated conditions in Karnataka. India. Indian J. Seric. 16: 10-18.

Kasiviswanathan, K., S. Krishnaswami and P. C. Chowdhury. 1979. Long-term studies on the variety, spacing and nitrogen fertilization for the improvement of yield potential of mulberry. Indian J Seric. 18: 23-29.

Miah, M. A. B. 1989. Studies on the growth and yield of mulberry (Morus alba L.). Ph.D. Thesis. University of Rajshahi, Bangladesh.

Mukherjee, S. K. and D. Sengupta. 1978. Studies on fertilizer, varieties, spacing, pruning and irrigation on mulberry leaf yield. Annual Report. Central Sericulture Research and Training Institute, Berhampur, India, 61-69.

Mukherjee, S. K., D. Ray and A. K. Pain. 1972. Influence of different levels of irrigation on the yield of bush mulberry raised under Bengal and Mysore systems of plantation. Indian J Seric. 11:33-38.

Pain, A. K. 1965. Effect of NPK fertilizers and their combinations on the yield and nutritive value of mulberry. Indian J. Seric. 4: 1-8.

Quader, M. A., M. A. Qayyum, A. A. Sarkar, M. A. Rab and S. U. Ahmed. 1992. Varietal response to NPK-fertilizers in combination with foliar spray of urea on leaf yield and quality of mulberry. Bull. Sericult. Res. 3: 54-66.

Rangaswami, G. M., M. N. Naramahanna, K. Kasiviswanathan and C. R. Sastry. 1976. Seiculture Manual. 1. Mulberry Cultivation, FAO, Rome.

Ray, D. 1978. Effect of different doses of ammonium sulphate and lime on soil composition, leaf yield and nutritive value of mulberry leaf. Annual Report. Central Striclure Research and Training Institute, Berhamapur, India. 5 I -55. 
Ray, D. and P. K. Chinya. 1972. Chemical composition of osage orange leaf (Maclura pomifera Raf.).Indiani. Seric. 11:39-42.

Subbarayappa, C. T., A. K. Sinha, P. Sandareswaran, N. R. Singhvi and R. K. Datta. 1994. Effect of split doses of fertilizers on yield of mulberry leaves. Indian J. Seric. 33: 72-73. 